\title{
自然気胸に対する胸腔鏡下治療 一局所麻酔下ブレブ切除術の検討一
}

\author{
根津 邦基，飯岡 壮吾，櫛部 圭司，澤端 章好 \\ 東条＼cjkstart尚，河内 寛治，北村惣一郎
}

\section{要 旨}

自然気胸14例に対し，局所麻酔下に胸腔鏡下手術を行った．局所麻酔治療の適応は，術前診断で胸膜 癒着がなく，ブレブが明かな症例とした。 14例中，高歯会気胸と急性膿胸を合併した 2 例を除く 12 例( 86 \%)で，治療を完遂しえた，手術方法は酒石酸ブトルファノールとジアゼパムの静注で鎮静し，前処置 として胸腔内へリドカインを注入し，3 カ所の挿入口より操作を行った. ブレブ処置法は Endo-GIAを 使用したものが 8 例，Endo-clip 使用が 2 例，Endo-GIA と Endo-clip の併用が 2 例であった.

局所麻酔下での術中，血行動態及び動脈血酸素飽和度には特に問題を認めなかった．術後合併症を認 めたものは 2 例で, 肺瘦と一過性無気肺であったが, 短期に回復し, 術後平均入院期間は5.5日であっ た. 自然気胸の胸腔鏡下手術を簡便化する一手段として，胸膜癒着がなく，ブレブが明かな症例では局 所麻酔下での治療が安全に完遂しえた.

索引用語：自然気胸, 胸腔鏡手術, 局所麻酔

Endo-GIA, spontaneous pneumothorax, thoracoscopic surgery, local anesthesia

\section{はじめに}

近年, ビデオシステムや胸腔鏡下手術器具の 進歩に伴い，胸腔鏡下治療が自然気胸の一治療 法として確立された感がある11.

現在，自然気胸の胸腔鏡下ブレブ切除術は一 般的に，全身麻酔下で片肺換気のもと術側肺を 虚脱させて行われている2,3). しかし，元来，胸 腔鏡は局所麻酔下で，胸腔内の診断や生検の手 段として用いられてきた ${ }^{4-6)}$ そこで著者らは， 自然気胸に対する胸腔鏡下手術を簡便化する一 手段として，術前診断で胸膜癒着がなく，ブレ ブが明かな症例に限り局所麻酔下に治療を試み た。今回，自然気胸に対する局所麻酔下手術 14

奈良県立医科大学 第 3 外科

原稿受付 1993年 9 月 29 日

原稿採択 1994 年 1 月12日
例の経験に基づき，疼痛の制御，手術手技の困 難性，術中の血行，換気動態，術後合併症の点 から本法の可能性, 安全性について検討した.

\section{対 象}

1991年 3 月より当科に扣いて胸腔鏡下手術を 行った自然気胸 30 例中, 局所麻酔下治療を扣こ なった14例（47\%）を対象とした。性別は男性 12例，女性 2 例で，年齢は17歳から78歳で平均 27歳であった。病側は右側 6 例，左側 8 例であ った．再発例が11例，初発例が 3 例であり，初 発例は胸腔内持続吸引を行なったが，肺膨張の 得られない症例であった。全例，術前胸部 X 線 と胸部 CT にてブレブの確認を抏こなった。 た，胸腔ドレーンより約 $500 \mathrm{ml}$ の空気を注入 し，注入後呼吸困難が出現しないことを確かめ， 注入後の胸部 X 線にて肺外側面全体が胸壁及び 縦隔胸膜と離れることにより，胸膜癒着が無い 
と判定した（Fig. 1). 局所麻酔下手術の適応と しては，（1）胸膜癒着を認めないもの，（2） 画像診断にてブレブの位置が明かなものとした.

\section{手術方法}

全例，手術室にて全身麻酔下への移行が可能 な体制で手術を行った，疼痛対策として，手術 開始30分前に胸腔ドレーンより $0.5 \%$ リドカイ ン(キシロカイン) $40 \mathrm{ml}$ を注入し，体位変換を 行うことにより浸潤麻酔をはかった．静脈確保 を行い, 酒石酸ブトルファノール(スタドール) $1 \mathrm{mg}$ ，ジアゼパム(セルシン) $5 \mathrm{mg}$ を静注し た、胸腔鏡は径 $5 \mathrm{~mm}$ のものを使用した。体位 は側臥位とし,酸素 2 L/分をマスクにて投与し た。心電図モニターと自動血圧計で血行動態を, そして手指尖の動脈血酸素飽和度モニターで動 脈血酸素飽和度を前投薬前より手術終了後まで 経時的にモニターした。

まず第 5 肋間中腋窩線上に $1 \%$ \%シロカイン
にて局所麻酔後, 肺損傷を防ぐため胸腔ドレー ンより約 $300 \mathrm{ml}$ の空気を注入した後, 径 $5 \mathrm{~mm}$ のトロッカー（サージポート）を胸腔内に挿入 した。そこよりテレビカメラを装着した径 5 $\mathrm{mm}$ の胸腔鏡を胸腔内に入れ, 術前の画像診断 で確認した病巣部を含め, 肺表面及び葉間を観 察した. 次に第 3 肋間後腋窩線より把持鉗子用 の径 $5 \mathrm{~mm}$ トロッカー, 第 4 肋間前腋窩線より Endo-GIA, Endo-Clip 用の径12 mm トロッカ 一を挿入した (Fig. 2). 術中, 3 カ所のトロッ カーは留置されたままで, 胸腔内は閉鎖状態で ある、トロッカーのコックより空気の注入ある いは排気を行らことにより，肺の虚脱と膨張を 行った. ブレブ切除後, 切除部にフィブリン糊 を散布した。操作後了終, 空気漏れの確認は卜 ロッカーのコックより空気を吸引し肺を膨張さ せた後，マスク下にバッグで陽圧換気を行うこ とにより抏こなった，中腋窩線部のトロッカー 挿入部より胸腔ドレーンを挿入し手術を終了し

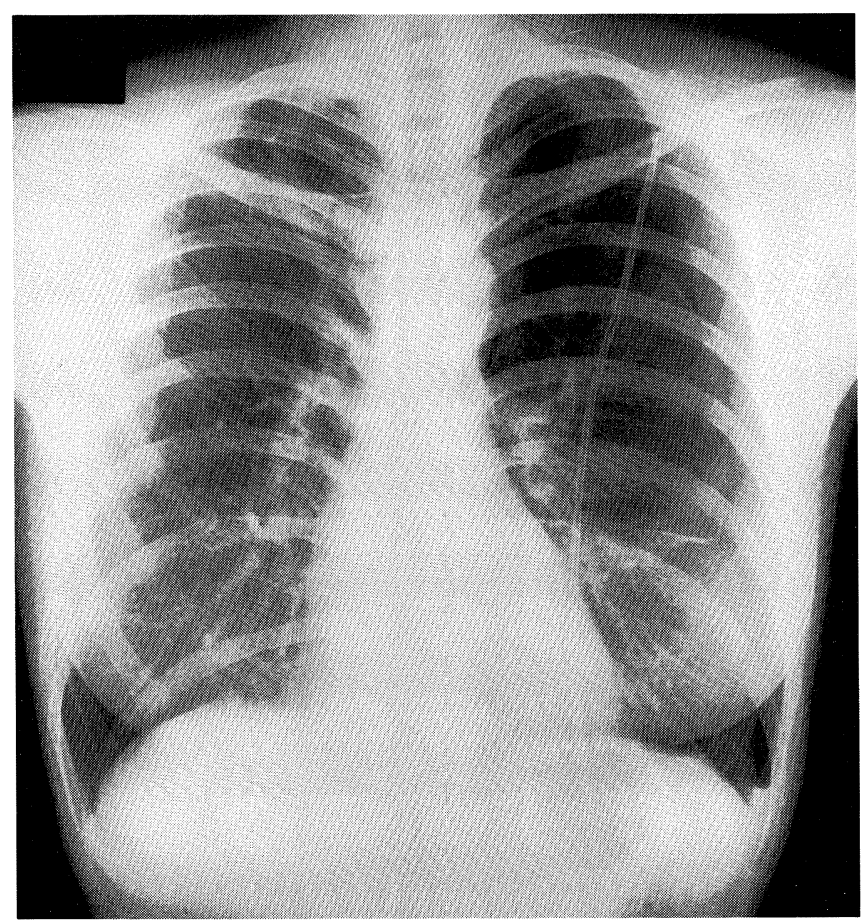

Fig. 1 Diagnosis of pleural adhesion. Room air, $500 \mathrm{ml}$, was injected into the left thoracic cavity, and no pleural adhesions were seen on chest $\mathrm{X}$-ray. 


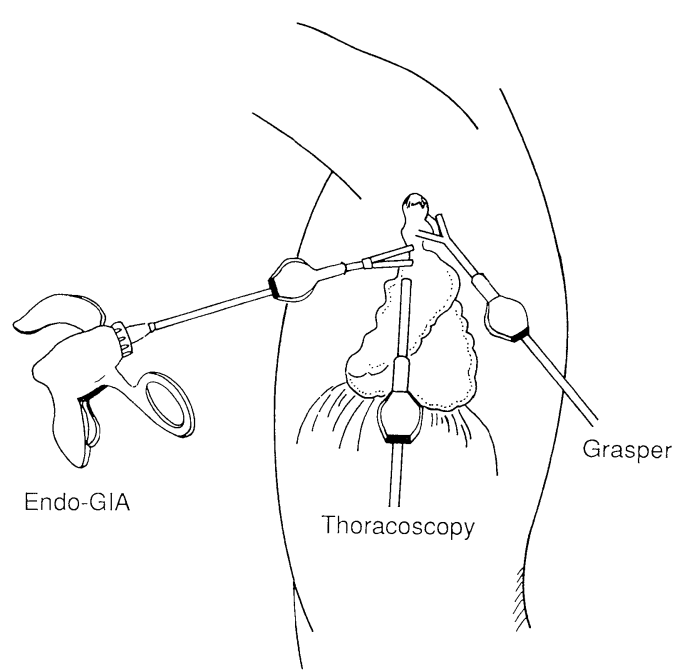

Fig. 2 Thoracoscopic operative procedures used in our patients.

た.

\section{検 討 方 法}

以上，局所麻酔下治療14例に対し治療成績抒 よび手術開始前とブレブ切除終了時点における 血行動態, 動脈血酸素飽和度, 血液ガスの変化 について検討した。 また, 退院後全例に, 術中 疼痛の有無と局所麻酔下手術の満足度について アンケートを执こなった。

\section{結果及び成績}

1. 局所麻西杂手術成功例 (Table 1) 14例 中，局所麻酔下胸腔鏡手術にて治療しえた 12 例 （成功率 $86 \%$ ）の治療内容を示す．年齢は17歳 から48歳で, 平均23歳であった. 病側は右側 5 例, 左側 7 例であった. 全例, 胸膜癒着は認め ず，空気注入テストによる術前診断は正確であ った. ブレブの位置は 12 例中 10 例が肺尖部にあ り，他に $\mathrm{S}^{3}$ が 1 例， $\mathrm{S}^{10}$ が 1 例であった. 12 例 中, $\mathrm{S}^{10}$ そブレブのあった症例を除いた 11 例 $(92$ \%) で, 術前の画像診断でのブレブの位置確認 と胸腔鏡所見とは一致した. ブレブの個数は 1 個から 4 個で平均1.8個であった.ブレブの処理 法は Endo-GIA による肺部分切除が 8 例, Endo-Clip による縫縮が 2 例, Endo-GIA と Endo-Clip を併用したものが 2 例であった. 1 個のブレブに対する Endo-GIA 平均使用回数 は1.5回であった. 術中, 空気漏れのテストに て，切断部からの空気漏れを 1 例（症例 2) に 認めた，手術時間は30分から70分で平均51分で あった. 全例術後 2 時間目には経口摂取可能で あった. 術後合併症は 2 例で確め, 症例 2 では 術後 3 日目玉で肺瘦が持続したため, 胸腔内に OK-432を $5 \mathrm{KE}$ 注入し肺瘦は消失した。症例 8 では術直後の胸部 X線にて右上葉の無気肺を

Table 1 Successful cases of thoracoscopic surgery under local anesthesia Case Age, Sex Op.side Location, Number Op. method $\underset{\text { (min) }}{\text { OP.time }}$ Complication $\begin{gathered}\text { Hospital stay } \\ \text { (Postop. days) }\end{gathered}$

\begin{tabular}{|c|c|c|c|c|c|c|c|c|}
\hline 1 & $33, \mathrm{M}$ & Lt & $\mathrm{S}^{10}$, & 1 & CLIP & 70 & $(-)$ & 7 \\
\hline 2 & 48, M & Rt & $\mathrm{S}^{1}$, & 3 & 3 - GIA & 60 & $\begin{array}{l}\text { Pulmonary } \\
\text { fistula }\end{array}$ & 7 \\
\hline 3 & $20, \mathrm{M}$ & $\mathrm{Rt}$ & $\mathrm{S}^{1}$, & 1 & 1 - GIA & 57 & $(-)$ & 6 \\
\hline 4 & $21, \mathrm{M}$ & Lt & $\mathrm{S}^{1+2}$, & 1 & $2-\mathrm{GIA}$ & 55 & $(-)$ & 5 \\
\hline 5 & $17, \quad F$ & $\mathrm{Rt}$ & $\mathrm{S}^{1}$, & 1 & 1 - GIA & 53 & $(-)$ & 5 \\
\hline 6 & $22, \mathrm{M}$ & $\mathrm{Rt}$ & $\mathrm{S}^{1}$, & 2 & 1-GIA + CLIP & 48 & $(-)$ & 5 \\
\hline 7 & 19, M & Lt & $\mathrm{S}^{3}$, & 1 & CLIP & 52 & $(-)$ & 5 \\
\hline 8 & $18, \mathrm{M}$ & $\mathrm{Rt}$ & $\mathrm{S}^{1} / \mathrm{S}^{2}$, & 4 & 4-GIA + CLIP & 63 & Atelectasis & 5 \\
\hline 9 & $20, \mathrm{M}$ & Lt & $\mathrm{S}^{1+2}$, & 2 & 2 - GIA & 30 & $(-)$ & 5 \\
\hline 10 & $22, \quad F$ & Lt & $\mathrm{S}^{1+2} / \mathrm{S}^{3}$, & 2 & 3 - GIA & 48 & $(-)$ & 5 \\
\hline 11 & $22, \mathrm{M}$ & Lt & $\mathrm{S}^{1+2}$, & 2 & 3 - GIA & 52 & $(-)$ & 6 \\
\hline 12 & $17, \mathrm{M}$ & $\mathrm{Rt}$ & $\mathrm{S}_{1}$, & 1 & $2-$ GIA & 45 & $(-)$ & 6 \\
\hline
\end{tabular}


Systolic BP

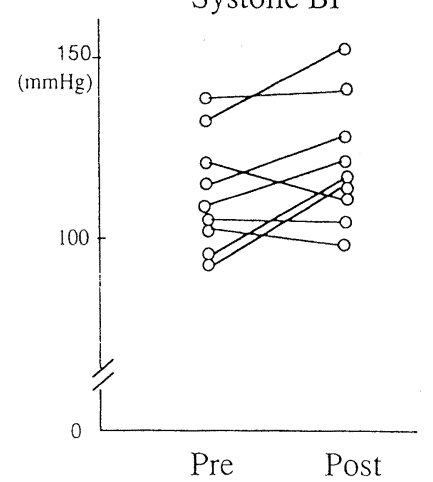

HR

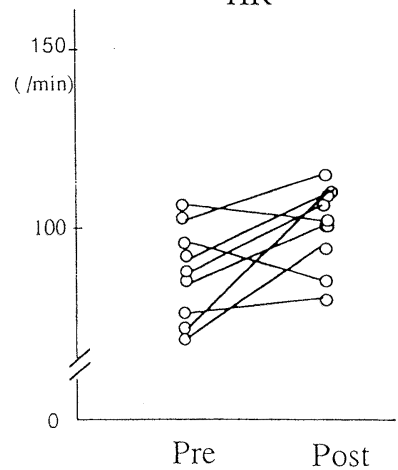

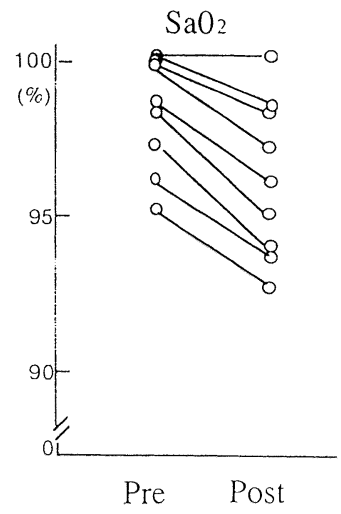

Fig. 3 Changes in hemodynamics and $\mathrm{SaO}_{2}$ during the operation.

認めたが, 気管支鏡下に右上葉支に空気を約 150 $\mathrm{ml}$ 注入することにより直ちに改善した. 術後ド レーンは症例 2 を除き, 術後 3 日目に抜去した. 術後入院期間は 5 日から 7 日で平均 5.5 日であ った.

術中血行動態及び動脈血酸素飽和度 (Fig. 3)：

12 例中 9 例で手術開始前とブレブ切除終了時 点で術中血行動態及び動脈血酸素飽和度の計測 を行った. 最高血圧は手術開始前 $113 \pm 15.2$ $\mathrm{mmHg}$ よりブレブ切除終了後 $120 \pm 16.5$ $\mathrm{mmHg}$ となり，9 例中 5 例で上昇をみたが, 150 $\mathrm{mmHg}$ を越光たものは 1 例のみであった。 心拍 数は開始前 $89 \pm 11.3$ より終了時 $99 \pm 9.1$ 回/分と なったが，120回/分を越えた症例はなかった。 動脈血酸素飽和度は開始前 $98 \pm 1.8 \%$ より終了 時 $97 \pm 2.5 \%$ となり 9 例中 8 例で $1 \sim 3 \%$ の低
下を認めたが，90\%以下となる症例はなかった。

術中血液ガス (Fig. 4)：6 例で術中動脈内カ テーテルを留置し, 手術開始前とブレブの処置 を終了した時点での動脈血酸素分圧と動脈血二 酸化炭素分圧の測定を打こなった. 2 L/分の酸 素マスク吸入下で測定した。術中, 動脈血酸素 分圧は 6 例中 3 例で $150 \mathrm{mmHg}$ 前後より 100 $\mathrm{mmHg}$ 前後まで低下したが, $90 \mathrm{mmHg}$ 以下と なる症例はなかった．動脈血二酸化炭素分圧で は50 mmHg 以上となる症例はなかった.

術後患者へのアンケート：術後最低 1 カ月を 経過した時点で，次のアンケートを和こなった． すなわち，（1）術中疼痛を感じたか，（2）局 所麻酔で手術してよかったかを質問した。その 結果，（1）の術中の疼痛に関しては12例中 1 例 だけが軽度の疼痛を感じ, 残りの11例では全く
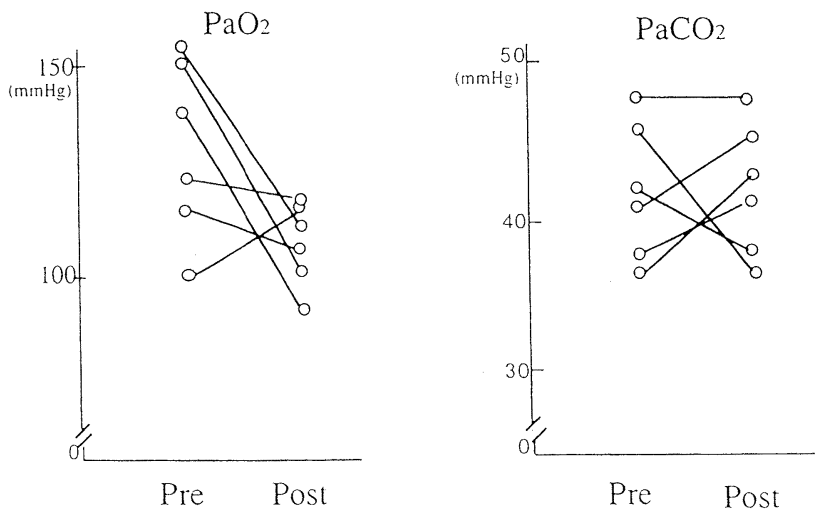

Fig. 4 Changes in $\mathrm{PaO}_{2}$ and $\mathrm{PacO}_{2}$ during the operation. 


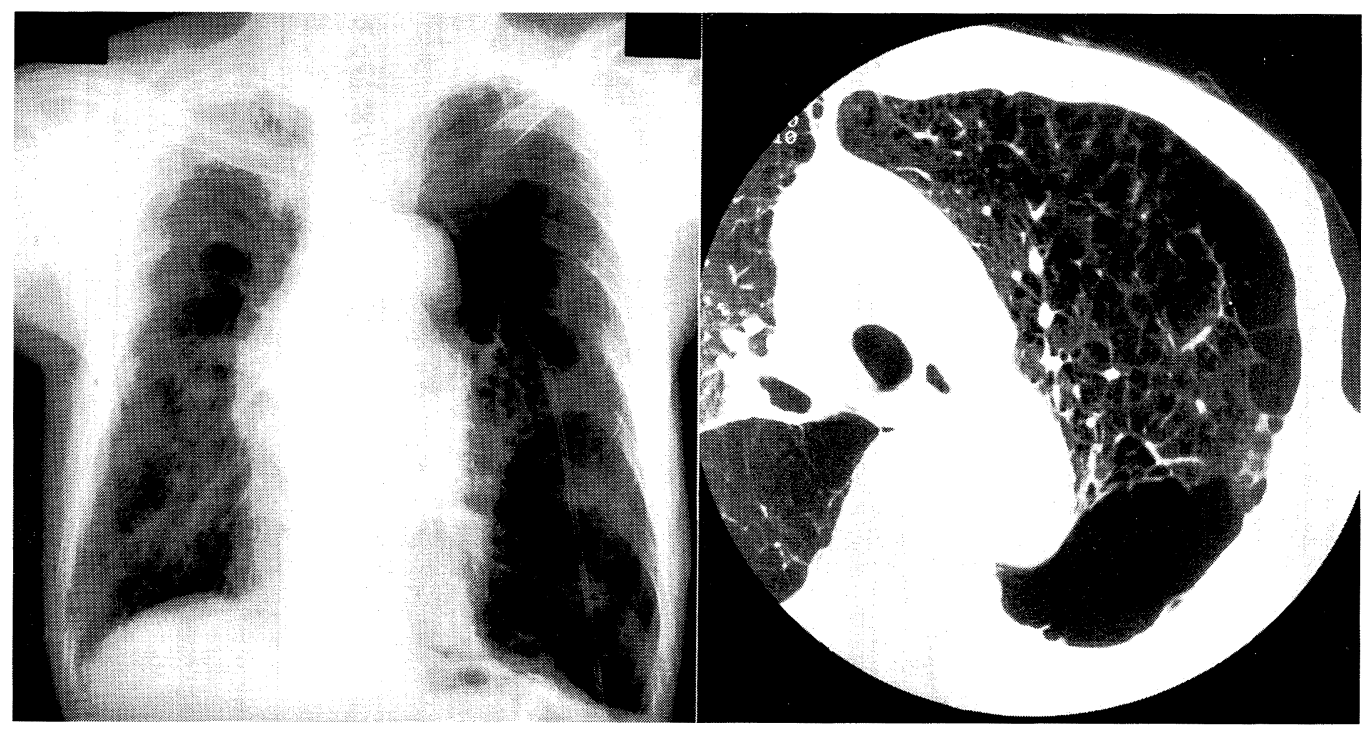

Fig.5 Unsuccessful case 1, a 78-year-old. male. a) : Chest X-ray showed a left pneumothorax. b) : Chest CT scans showed the emphysematous lung and bullas at $\mathrm{S}^{1+2}$ and $\mathrm{S}^{6}$. $\mathrm{He}$ devoloped dyspnea during the procedure because of anxiety and/or emphysema.

疼痛を感じなかったと回答した。（2）の質問に は局所麻酔下の手術でよかった：10例，よくわ からない：2 例であった. 患者へのアンケート の結果からはほとんどの患者で, 局所麻酔下治 療で十分満足したという回答を得られた。

\section{2. 局所麻酔下治療不成功例}

14例中 2 例 (14\%) で局所麻酔下手術にて完 遂しえず，結局，開胸手術となった。この 2 例 の不成功原因を簡潔に述べる.

（不成功症例 1）78歳, 男性. 左胸痛出現し, 左気胸と診断され胸腔ドレナージを受けた (Fig. 5a). 胸部 CT では全体に肺気腫を認め, $\mathrm{S}^{1+2}$ と $\mathrm{S}^{6}$ にブラを認めた (Fig. 5b). 手術開始 約15分後より呼吸困難を訴光た。呼吸困難を訴 えた際の血液ガスは動脈血酸素分圧77.0 $\mathrm{mmHg}$, 動脈血二酸化炭素分圧 $38.0 \mathrm{mmHg}$ と 異常值を示していなかった. 胸腔鏡下に $\mathrm{S}^{1+2}$ と $\mathrm{S}^{6}$ のブラを Endo-GIA にて切除したが, 術後 肺瘻が持続したため, 術後 6 日目に開胸術を施 行した. 局所麻酔下で高龄者患者の不安感を充 分に取り除くことができなかったことが不成功 の主な原因と考㝋られた。

（不成功症例 2）18歳, 男性. 左気胸を発症
し，同時に $37^{\circ} \mathrm{C}$ の発熱がみられた. ドレナージ 後持続吸引を行らも肺膨張が得られず，発症よ り 2 週間後に当科に紹介入院となった. 術中, 胸腔鏡を抻入すると黄色の混濁した胸水の貯留 をみとめた. 肺全体はフィブリンの被膜で被わ れ，上葉は縦隔側で広範囲に癒着を認めた。以 上の所見より肺癒着を伴う急性膿胸と診断し, 肺全面の癒着剝離は困難であると判断したため, 胸腔鏡下手術を断念した。

\section{考察}

近年, 胸腔鏡下手術器具の開発により, 自然 気胸に対する治療の一手段として, 胸腔鏡下手 術が脚光を浴びるようになってきた，元来，胸 腔鏡が胸水の診断や腫瘍の生検を目的に用いら れていた際，手術は多くの場合局所麻酔下で行 なわれていた ${ }^{4-6)}$.その後, 武野らフは自然気胸に 対する治療法として, 局所麻酔下で 1 力所の挿 入口より，ブレブを電気凝固する方法を報告し た.しかし，この電気凝固法では，ブレブの径 が $1 \mathrm{~cm}$ 以下での再発率は $1 \%$ 以下であったが, $4 \mathrm{~cm}$ 以内の症例での再発率は $17.4 \%$ となった ことょり, 術式の適応が小さなブレブに限られ 
た. これに対し最近， $3 \mathrm{~cm}$ 以上で広基性のブ レブに対しても，Endo-GIAを用いて肺部分切 除を行い良好な成績を得ることが可能となっ $た^{8,99}$ 。我々は手術手技の習熟とともに，自然気 胸に対する胸腔鏡下手術はより簡便化できるの ではないかと考党, 癒着がなく, ブレブの位置 が明かな症例を適応として局所麻酔下での手術 を行った.

局所麻酔下で行らことの利点として，まず医 療者側としては，麻酔医を必要としないこと， 全身麻酔後の呼吸, 循環管理を省略でさるなど があげられる，患者側としては，全身麻酔薬や 挿管チューブによる損傷やリスクから逃れられ る. 術後数時間後には経口摄取も可能であり, 回復が早いこともあげられる，一方，局所麻酔 下での胸腔鏡下手術の不安点，リスクとしては 次の様な点が挙げられよう。（1）疼痛の制御が 可能か，（2）手術手技は困難でないか，（3） 術中の血行動態, 換気は問題ないか，(4)術後 の合併症はどの程度か，などである．その $4 つ$ の問題点について，今回の成績をもとに検討し た.

\section{（1）疼痛の制御が可能か}

局所麻酔下で 3 カ所の挿入口より操作を行う 場合，充分な疼痛抑制が出来るかが問題である. われわれは壁側胸膜に対する疼痛軽減を目的と して, 術前に $0.5 \%$ リドカインの胸腔内注入を行 ったささらに，酒石酸ブトルファノールとジア ゼパムの静注を加えた。これにより，患者は傾 眠状態であるが，問いかけには十分応答可能で あった，術後のアンケートでは 12 人中 1 人を除 く全例で，術中疼痛を感じなかったことより， 疼痛の制御は十分可能であると判断した.

（2）手術手技が困難ではないか

本検討では手術手技が容易に行い得るように, 癒着がなく，ブレブの位置が明かな症例を選択 した．術前の空気注入テストにて胸膜の癒着が ないことを診断した．本法により1例の急性膿 胸合併例を除き，他の13例（93\%）で痊着の無 いことを診断出来, 空気注入テストは有用な診 断法であった.ブレブの位置は，胸部単純 X線 像と胸部 CT とにより術前診断した。手術時胸
腔鏡を挿入し直ちにとの部位を確認することが できた. ブレブの切除は Endo-GIA 平均 2 回と Endo-clip を用いることにより容易に行うこと ができ，手術時間は平均51分で浪とんどの症例 で 1 時間以内に手術は終了した。

（3）術中の血行動態, 換気について

全身麻酔下では麻酔医により血行動態と換気 状態の監視が行われているが，局所麻酔下では 肺虚脱中の血行動態と換気について不安がもた れる。しかし，局麻下の手術が施行し光た12例 では術中血行動態と動脈血酸素飽和度は，若干 の変化はあったものの特に問題を認めず，局麻 下での肺虚脱による血行動態及び換気に与觉に 影響については，大部分の症例では問題ないこ とが示された．不成功症例 1 では広範囲肺気腫 の合併と不安感による呼吸困難が原因であった。 術中の経皮酸素飽和度のモニタ一は必要であろ 万.

(4) 術後合併症について

術後合併症（少量の肺瘦と無気肺）を認めた ものは 2 例（17\%）であったが， 2 例とも極く 短期に完治し克，早期退院可能であった.

今回の検討から著者らは胸腔鏡下手術の簡便 化の一手段として（1）胸膜癒着がなく（2） ブレブの位置が明かな症例では局所麻酔下での 治療が充分可能で且つ安全に施行しうると判断 し，今後とも本法を続行することとした.

本論文の要旨は第 10 回呼吸器外科学会総会に 执いて報告した。

\section{文献}

1) Wakabayashi A: Expanded application of diagnostic and therapeutic thoracoscopy. J Thorac Cardiovasc Surg 102 : 721-723, 1991.

2) Landreneau RJ, Mack MJ, Hazelrigg SR, et al: Video-assisted thoratic surgery: Basic technical concepts and intercostal approach strategies. Ann Thorac Surg 54: 800-807, 1992.

3) Melvin WS, Krasna MJ, McLaughlin JS: Thoracoscopic management of spontaneous pneumothorax. Chest 102: 1877-1879, 1992.

4) Oldenburg FA, Newhouse MT: Thoracoscopy. A safe, accurate diagnostic procedure using the rigid thoracoscope and local anesthesia. Chest $75:$ 45-50, 1979. 
5) Enk B, Viskum K : Diagnostic thoracoscopy. Eur J Respir Dis 62 : 344-351, 1981.

6) Davidson AC, George RJ, Sheldon CD : Thoracoscopy : assessment of a physician service and comparison of a flexible broncoscope used as a thoracoscope with a rigid thoracoscope. Thorax 43: 327-332, 1988.

7）武野良化：胸腔鏡下ブラ治療法, 外科治療
$66:$ 199-204, 1992.

8）浦上年彦，小林 徹，松井 寛：胸腔鏡を用い た気胸手術の検討. 日呼外合誌 $7: 472-476$, 1993.

9）八板英道, 石田照佳, 杉町圭蔵：ENDO GIA 30 を用いた胸腔鏡下ブレブ切除術の臨床的検討. 日呼外会誌 $7: 442-447,1993$.

\title{
Thoracoscopic surgery for spontaneous pneumothorax under local anesthesia
}

\author{
Kunimoto Nezu, Sogo Iioka, Keiji Kushibe, Noriyoshi Sawabata \\ Takashi Tojo, Kanji Kawachi, Soichiro Kitamura \\ Department of Surgery III, Nara Medical College
}

Thoracoscopic resection of a bleb or a bulla was performed under local anesthesia in 14 patients with spontaneous pneumothorax. Indications were the absence of parietal pleural adhesion and the precise identification of the location of the bleb prior to the procedure. Before the operation, $0.5 \%$ lidocaine was administered intrathoracically and butorphanoltartrate plus diazepam intravenously to reduce pain and anxiety during the procedure. The method utilized was the 3-puncture technique. The resection was performed with an Endo-GIA, Endo-CLIP and Endo-GIA plus Endo-CLIP in 8, 2 and 2 patients, respectively. The thoracoscopic surgery under local anesthesia was quite successful in all but 2 patients (success rate $86 \%$ ). The 2 unsuccessful cases were an elderly patient with empyema who developed dyspnea during the procedure and a patient with acute empyema resulting in adhesion of the parietal pleura. There were no particular problems encountered during the procedure in terms of stability of hemodynamics or arterial blood gas abnormalities. Postoperative complications were seen in 2 patients (pulmorary fistula and transient atelectasis). The average duration of hospitalization after the procedure was 5.5 days. Thoracoscopic surgery under local anesthesia can be performed safely is patients with spontaneous pneumothorax when pleural adhesion is absent and the location of blebs is known. We believe that this technique can further simplify thoracoscopic surgery for pneumothorax. 